\title{
PENGARUH MODEL PEMBELAJARAN KOOPERATIF TIPE TWO STAY TWO STRAY (TSTS) DAN KOMPETENSI PEDAGOGIK GURU TERHADAP HASIL BELAJAR ILMU GIZI SISWA KELAS X JURUSAN TATA BOGA DI SMKN 2 SINGARAJA
}

\author{
I Gusti Ayu Made Sukelasmini, I Nyoman Natajaya, I Gusti Ketut Arya Sunu \\ Program Studi Administrasi Pendidikan, Program Pascasarjana \\ Universitas Pendidikan Ganesha \\ Singaraja, Indonesia
}

e-mail: \{made.sukelasmini,nyoman.natajaya, arya.sunu\}@pasca.undiksha.ac.id.

\begin{abstract}
Abstrak
Penelitian ini bertujuan untuk mengetahui pengaruh model pembelajaran kooperatif tipe two stay two stray (TSTS) dan kompetensi pedagogik guru terhadap hasil belajar ilmu gizi siswa kelas $\mathrm{X}$ Jurusan Tata Boga di SMKN 2 Singaraja. Penelitian ini adalah penelitian eksperimen dengan menggunakan rancangan penelitian semu dengan pola "The Posttest-Only Control Design".denganbesar sampel 72 orang. Data dikumpulkan dengan tes.Analisis data dilakukan dengan Anakova. Hasil penelitian menunjukkan bahwa: 1) terdapatpengaruh yang signifikan model pembelajaran kooperatif Two Stay Two Stray terhadap hasil belajar ilmu gizi siswa kelas X Jurusan Tata Boga di SMKN 2 Singaraja. Kualifikasi hasil belajar dengan menggunakan model pembelajaran kooperatif tipe TSTS berada pada katagori sangat tinggi, dan hasil belajar dengan menggunakan pembelajaran konvensional berada pada katagori tinggi. 2) terdapatterdapat pengaruh yang signifikan model pembelajaran kooperatif Two Stay Two Stray terhadap hasil belajar ilmu gizi siswa kelas X Jurusan Tata Boga di SMKN 2 Singaraja setelah kovariabel kompetensi pedagogik guru. 3) terdapatterdapat kontribusi yang signifikan kovariabel kompetensi pedagogik guru terhadap hasil belajar ilmu gizi siswa.Berdasarkan temuan-temuan di atas dapat disimpulkan bahwa model pembelajaran kooperatif tipe TSTS berpengaruh terhadap hasil belajar baik sebelum maupun setelah kovariabel kompetensi pedagogik dikendalikan.
\end{abstract}

Kata kunci: TSTS, kompetensi pedagogik, hasil belajar

\begin{abstract}
This study aims to determine the effect of cooperative learning model type two stay two stray (TSTS) and teacher pedagogic competence to the results of nutrition learning of $X$ class students of Department of Culinary at SMKN 2 Singaraja. This research is experimental research by using quasi research design with pattern "The Posttest-Only Control Design". with a large sample of 72 people. Data collected by test. Data analysis was performed with Anakova. The results showed that: 1) there is a significant effect of Two Stay Two Stray cooperative learning model toward the result of learning science of nutrition of $X$ class students of Department of Culinary at SMKN 2 Singaraja.Student learning outcomes using cooperative learning model TSTS type higher than the learning outcomes using conventional learning. Qualification of learning outcomes by using TSTS type cooperative learning model is very high, and learning outcomes using conventional learning are in high category. 2) there is a significant effect of Two Stay Two Stray cooperative learning model toward the students 'learning outcomes of $X$ grade Department of Culinary at SMKN 2 Singaraja after the covariabel of teachers' pedagogic competence is controlled. 3) there is a significant contribution of teacher pedagogic covariable competence to students' nutritional learning outcomes. Based on the above findings it can be concluded that the cooperative learning model of TSTS type influences the learning outcomes both before and after the covariabel of pedagogic competence is controlled
\end{abstract}

Keywords: TSTS, pedagogic competence, learning outcomes 


\section{PENDAHULUAN}

Sekolah merupakan sarana untuk peserta didik memperoleh ilmu pengetahuan dan mengembangkan keterampilan dalam kegiatan belajar, selain itu sekolah juga memberikan pendidikan moral dan etika sehingga dapat menghasilkan perubahan tingkah laku yang baik bagi peserta didik. Oleh karena itu sekolah sebagai pusat pendidikan harus bisa melaksanakan fungsinya dengan baik untuk menyiapkan generasi muda yang nantinya dapat membangun bangsa. Aktivitas belajar merupakan kegiatan pembelajaran yang dilakukan oleh siswa, dimana siswa berperan aktif dalam proses pembelajaran sehingga akan menghasilkan pengetahuan, pengalaman, pemahaman dan aspek-aspek lain. Kenyataannya di dalam kegiatan pembelajaran masih ada juga siswa yang terlihat kurang antusias dalam belajar, dan banyak yang asyik mengobrol dengan teman lainnya tanpa menghiraukan penjelasan guru serta siswa merasa bosan.Pastinya seorang guru berharap agar suasana di dalam kelas benar-benar hidup dan semua siswa dapat termotivasi terhadap pelajaran.

Guru sebagai pengajar dan pendidik berperan untuk memberikan ilmu yang dimilikinya kepada peserta didik dan memberikan pembinaan yang berhubungan dengan kedisiplinan peserta didik. Di dalam proses pembelajaran guru merupakan penentu keberhasilan belajar peserta didik. Oleh karena itu, guru harus berupaya agar kegiatan di kelas dapat memberikan kesempatan yang luas untuk pengalaman siswa.Guru juga harus bisa memilih dan menerapkan metode pembelajaran yang sesuai, sehingga kegiatan pembelajaran dapat diselenggarakan dengan efektif.

Hasil belajar dipengaruhi oleh berbagai faktor, baik faktor dari dalam (internal) maupun faktor dari luar (eksternal).Menurut Sukmadinata (2009: 162-165) yang termasuk faktor internal adalah faktor fisiologis dan psikologis (misalnya kecerdasan motivasi berprestasi dan kemampuan kognitif), sedangkan 5 yang termasuk faktor eksternal adalah faktor lingkungan dan instrumental (misalnya guru, kurikulum, dan model pembelajaran).Suprijono (2009:6) mengemukakan tiga faktor utama yang mempengaruhi hasil belajar, yaitu kemampuan kognitif, motivasi berprestasi dan kualitas pembelajaran. Kualitas pembelajaran adalah kualitas kegiatan pembelajaran yang dilakukan dan ini menyangkut model pembelajaran yang digunakan.

Proses pembelajaran sebagai salah satu elemen penting dalam pendidikan di SMK (Sekolah Menengah Kejuruan) memiliki peranan besar dalam memediasi dan mengakomodasi usaha peningkatan kemampuan berpikir dan keterampilan peserta diklat menuju perubahan perilaku yang positif. Lindgren (1967:7) memandang hal ini sebagai suatu proses yang berkesinambungan dan berkemajuan, sebagaimana yang dikemukakannya bahwa:

the learning process is process by which people acquire changes in their behavior, improve performance, reorganize their thinking, or discover new ways of behaving and new concepts and information. Learning is always going on: it is a process that begins at birth (or perhaps even before) and continues in some form or other troughout our lives.

Pada konteks ini, proses pembelajaran diharapkan mampu menggerakkan peserta diklat untuk mengoptimalkan sumber daya yang telah dimilikinya, sehingga mampu menemukan pengetahuan atau informasi baru yang dapat diterapkan dalam kondisi-kondisi nyata.

Proses pembelajaran yang mengedepankan pemberdayaan kemampuan peserta diklat harus dilakukan dalam setiap proses belajar mengajar di SMK, sebagaimana yang diamanatkan dalam UU No. 20 Tahun 2003 Bab 2 Pasal 3 tentang fungsi dan tujuan pendidikan nasional, bahwa proses pendidikan harus diselenggarakan dengan berorientasi pada pembudayaan, pemberdayaan, pembentukan watak dan kepribadian, serta berbagai kecakapan hidup. Hal ini menjadi sangat substansial ketika tantangan di era globalisasi semakin nyata dan kompleks.Pembelajaran di SMK dilaksanakan dalam kerangka pembentukan Standar Kompetensi Lulusan (SKL) peserta didik. Pembelajaran di SMK menggunakan paradigma outcome yaitukompetensi apa yang harus dikuasai peserta didik bukan pembelajaran yang memaksakan apa yang harus diajarkan oleh seorang guru. 
Paradigma pembelajaran di pendidikan menengah kejuruan harus berubah ke paradigma baru yaitu pembelajaran yang memperhatikan demand driven, mengacu kepada standar kompetensi yang berlaku di dunia kerja atau dunia industri (SKKNI), dilaksanakan dengan sistim ganda di sekolah dan di industri atau dunia usaha, dalam bentuk kegiatan nyata.Pembelajaran kompetensi berpusat pada peserta didik.Peserta didik sebagai subyek dan perbedaan individu dihargai secara objektif.

Fenomena di lapangan menunjukkan bahwa proses pembelajaran di SMK mengalami kecenderungan yang kontraproduktif dengan harapan di atas. Hal ini dapat dilihat pada beberapa penelitian tentang proses pembelajaran di SMK (Rusyana, 2006; Abdulrohim, 2007) yang menggambarkan bahwa proses tersebut berlangsung secara monoton atau tidak ada variasi, berpusat pada guru, dan kurang melibatkan peran aktif peserta diklat. Studi tersebut sesuai dengan pandangan Purba (Kompas, 2006) yang menyatakan bahwa kenyataannya pembelajaran di SMK masih mengedepankan tatap muka di ruang kelas.Bahkan, tidak sedikit peserta didik di sejumlah SMK baik teknologi maupun industri yang tidak diberi pelajaran praktek sesungguhnya. Kondisi ini tentunya akan berdampak pada hasil belajar peserta diklat yang cenderung kurang maksimal, sebagaimana yang diungkapkan pada beberapa penelitian.

Seperti halnya pembelajaran yang dilakukan di SMKN 2 Singaraja. SMK ini termasuk SMK yang banyak diminati karena mutu pendidikan di SMK ini sudah lumayan baik, akan tetapi berdasarkan observasi yang telah dilakukan peneliti di SMK ini, peneliti menemukan kenyataan bahwa dalam proses pembelajaran IImu Gizi, guru masih menggunakan metode ceramah sehingga guru belum dapat mendekatkan siswa dengan pengalaman belajarnya dan siswa masih kurang dalam hal kemampuan berpikir kritis, kreatif, serta mengkonstruksi pengetahuannya. Peran guru di dalam kelas masih sangat dominan dan keterlibatan siswa dalam proses pembelajaran sangat terbatas, sehingga pembelajaran masih bersifat satu arah. Keadaan kelas cukup ramai karena ketika guru ceramah, ada beberapa siswa yang sering ijin kebelakang, ijin sakit, cerita sendiri di dalam kelas, dan bahkan ada yang mengantuk. Hal ini dikarenakan model belajar yang digunakan oleh guru kurang menarik siswa untuk belajar.

Permasalahan seperti inilah yang perlu diperhatikan oleh setiap guru. Guru harus dapat menerapkan berbagai variasi metode berkelompok yang sesuai dengan keadaan kelas dan siswanya. Keberhasilan suatu proses pembelajaran dapat diukur dari keberhasilan siswa mengikuti pembelajaran tersebut. Sedangkan hasil belajar yang baik harus didukung oleh pembelajaran yang berkualitas yakni pembelajaran yang mampu menumbuhkan motivasi. Pembelajaran akan lebih optimal jika pendekatan atau model yang digunakan tepat. Model pembelajaran seperti ini meniadakan persaingan individu, menumbuhkan sikap demokratis dan melatih kemampuan memecahkan suatu tugas yang diberikan. Alternatif yang dapat dipilih untuk membuat pelajaran IImu Gizi lebih menarik dan menyenangkan, dapat meningkatkan keaktifan siswa serta pelajaran IImu Gizi lebih mudah dipahami, guru dapat menerapkan dan mengembangakan model pembelajaran kooperatif tipeTwo Stay Two Stray (TSTS)untuk pembelajaran IImu Gizi pada materi di sekolah.

Model pembelajaran kooperatif tipe Two Stay Two Stray menurut Huda seperti dikutip Purmiati dkk, yaitu tipe pembelajaran kooperatif dengan masing-masing kelompok diberikan kesempatan untuk membagikan hasil informasi yang telah didiskusikan kepada kelompok lain. Model ini memiliki variasi berkelompok dalam pembelajarannya. Model pembelajaran kooperatif tipeTwo Stay Two Stray membuat siswa memiliki peran dan tanggung jawab untuk mengerjakan tugas, dimana masing-masingkelompok saling beriteraksi mensharing informasi, sehingga pengetahuan dan pemahaman siswa menjadi berkembang.

Lie (2010:61) juga mengungkapkan bahwa dalam struktur model pembelajaran kooperatif tipe Two Stay Two Stray memberi kesempatan kepada kelompok untuk membagikan hasil dan informasi dengan kelompok lain. Melalui struktur model pembelajaran kooperatif tipe Two Stay Two Stray ini, siswa dibagi menjadi beberapa kelompok heterogen, masing-masing kelompok 4 siswa. Mereka berdiskusi atau bekerja sama membuat laporan suatu peristiwa dengan tema tertentu yang disampaikan guru. Setelah selesai, dua siswa dari masing-masing kelompok 
akan bertamu ke kelompok lain. Dua siswa yang tinggal dikelompoknya bertugas membagi hasil kerja atau menyampaikan informasi kepada tamu mereka.Siswa yang menjadi tamu mohon diri dan kembali ke kelompok mereka sendiri. Mereka melaporkan hal yang didapat dari kelompok lain, kemudian siswa membuat laporan tentang hasil diskusi tersebut.

Selain model pembelajaran yang digunakan, tentunya ada aspek lain yang sangat mempengaruhi hasil belajar siswa. Diantaranya adalah kompetensi yang dimiliki oleh guru, khususnya kompetensi pedagogik.Kompetensi pedagogikmerupakan salah satu jenis kompetensi yang mutlak perlu dikuasai guru. Kompetensi pedagogik pada dasarnya adalah kemampuan guru dalam mengelola pembelajaran peserta didik. Kompetensi pedagogik merupakan kompetensi khas, yang akan membedakan guru dengan profesi lainnya dan akan menentukan tingkat keberhasilan proses dan hasil pembelajaran peserta didiknya.

Karena seorang guru merupakan seorang yang menjadi sentral dalam pembelajaran yang harusnya bertanggung jawab terhadap berbagai perencanaa, pelaksanaan, dan penilaian perubahan atau perbaikan dari program pembelajaran. Jadi sangat penting seorang guru harus bisa dan memiliki kemampuan dalam mengelola pembelajaran agar proses pelaksanaan pembelajaran bisa berjalan lancar dan menarik minat peserta didik dalam kegiatan belajar mengajar.

Berdasarkan penjelasan diatas, model pembelajaran kooperatif tipe Two Stay Two Strayini secara teoritis dapat dijadikan bahan kajian pengembangan penelitian. Maka dari itu peneliti ingin mencoba melakukan penelitian dengan judul: "Pengaruh Model Pembelajaran Kooperatif Tipe Two Stay Two Stray (TSTS) dan Kompetensi Pedagogik Guru terhadap Hasil Belajar IImu Gizi Siswa Kelas X Jurusan Tata Boga di SMKN 2 Singaraja".

\section{METODE PENELITIAN}

Rancangan penelitian yang digunakan dalam penelitian ini adalah Posttest Only Control Group Design.Penelitian ini menggunakan metode eksperimen, dengan menggunakan kelompok eksperimen dan kelompok kontrol. Pada kelompok eksperimen asesmen pembelajaran dilaksanakan menggunakan model pembelajaran kooperatif tipe two stay two stray, sedangkan pada kelompok kontrol, asesmen pembelajaran dilaksanakan dengan pembelajaran konvensional.

Populasi merupakan wilayah generalisasi, terdiri atas objek/subjek yang memiliki kualitas dan karakteristik tertentu yang dapat diterapkan peneliti untuk dipelajari dan kemudian ditarik kesimpulan (Sugiyono, 2008:32). Sedangkan menurut Agung $(2014 ; 69)$ menyatakan populasi adalah keseluruhan objek dalam suatu penelitian. Populasi pada penelitian ini adalah seluruh siswa kelas X Jurusan Tata Boga di SMKN 2 Singaraja, yang berjumlah 144 orang.

Menurut Agung $(2016 ; 8)$ menyatakan bahwa sampel merupakan bagian dari populasi yang secara langsung dikenai penelitian. Berdasarkan karakteristik populasi, maka pengambilan sampel pada penelitian ini dilakukan dengan menggunakan teknik random sampling (Arikunto, 2005:56). Pada pemilihan sampel penelitian, tidak dilakukan pengacakan individu karena tidak bisa mengubah kelas yang telah terbentuk sebelumnya. Dengan demikian, diharapkan kemungkinan-kemungkinan pengaruh dari keadaan subjek mengetahui dirinya dilibatkan dalam eksperimen dapat dikurangi sehingga penelitian ini benar-benar menggambarkan dari pengaruh perlakuan yang diberikan.

Sampel pada penelitian ini dilakukan tanpa adanya pengacakan individu, cara ini dipilih dengan mempertimbangkan sulitnya untuk merubah kelas yang sudah terbentuk. Kelas dipilih sebagaimana yang telah terbentuk tanpa adanya campur tangan dari peneliti.

Berdasarkan dari karakteristik populasi dan tidak bisa dilakukan pengacakan individu, maka pengambilan sampel pada penelitian ini dengan teknik random sampling. Untuk lebih meyakinkan kedua kelompok yang menjadi sampel tidak berbeda secara signifikan, maka dilakukan uji kesetaraan kelas dengan menggunakan analisis anava satu jalur. 
Nilai $F$ hitung sebesar 0,988 dengan signifikansi sebesar 0,401 . Hasil tersebut menunjukkan bahwa signifikansi lebih besar dari 0,05, sehingga dapat disimpulkan bahwa tidak ada perbedaan kemampuan siswa atau kemampuan siswa setara.

Penelitian ini meyelidiki pengaruh dua variabel bebas terhadap dua variabel terikat.Variabel independent (bebas) tersebut adalah variabel yang mempengaruhi atau menjadi sebab perubahan variabel terikat. Variabel dependen (terikat) adalah variabel yang dipengaruhi atau yang menjadi akibat karena adanya variabel bebas.Kedua variabel bebas tersebut adalah yakni variabel model pembelajaran kooperatif tipe two stay two stray dan model pembelajaran konvensional. Model pembelajaran kooperatif tipe two stay two stray diberikan pada kelompok eksperimen dan model pembelajaran konvensional diberikan pada kelompok kontrol. Sedangkan variabel terikat yang diteliti dalam penelitian ini adalah kompetensi pedagogik dan hasil belajar.Kompetensi pedagogik guru adalah skor yang diperoleh jawaban kuesioner guru.Sedangkan hasil belajar di dapatkan dari hasil tes pada akhir penelitian.

Penelitian pendahuluan perlu dilakukan untuk pengumpulan data awal tentang efektivitas program bantuan operasional sekolah. Penelitian pendahuluan dilakukan oleh peneliti untuk menjajaki dapat tidaknya sesuatu peneliti ingin mengtahui apakah rencana penelitiannya memang masih memungkinkan untuk dilaksanakan.Bila ternyata tidak memungkinkan untuk penelitian ini makapeneliti harus rela tidak melanjutkan cencana penelitiannya dan segera mengganti denga mencari kemungkinan permasalahan baru.Penelitian pendahuluan dilakukan melalui wawancara dengan guru di SMKN 2 Singaraja.dan penanggung jawab program pembekalan, siswa dan para guru dan komite sekolah. Hasil penelitian pada pendahuluan mendapatkan data awal yang berupa masalah-masalah yang dialami dalam metode supervisi yang sudah diterapkan selama ini.

Data yang dikumpulkan dalam penelitian ini meliputi: 1) kompetensi pedagogik guru-guru di SMKN 2 Singaraja, 2) hasil belajar siswa di SMKN 2 Singaraja, dan 3) respon guru terhadap penerapan model pembelajaran kooperatif tipe two stay two stray.

Pendeskripsian data hasil belajar siswa dan kompetensi pedagogik guru berdasarkan tendensi data, meliputi mean, median, modus, standar deviasi, varians, rentangan, skor maksimum, dan skor minimum. Sebaran data hasil belajar dan kompetensi pedagogik guru disajikan dalam bentuk tabel dan gambar diagram untuk masing-masing pembelajaran konvensional.

Kualifikasi data hasil belajar dan kompetensi pedagogik guru, juga menggunakan analisis univariant. Analisis ini didasarkan pada skor rerata ideal (Mi) dan simpangan baku ideal (SDi). Kriteria kualifikasi perubahan data hasil belajar dan kompetensi pedagogik guru digolongkan menjadi lima. Untuk analisis kovarian diperlukan beberapa persyaratan analisis adalah uji normalitas sebaran data, uji homogenitas varians, dan uji linieritas.

Analisis data yang digunakan adalah Anakova.Untuk menguji hipotesis 1, digunakan analisis varians satu jalur.Untuk menguji hipotesis 2, digunakan analisis kovarian satu jalur dengan kovariabel kompetensi pedagogic.Untuk menguji hipotesis 3, yaitu mengetahui hubungan kovariabel kompetensi pedagogik guru terhadap hasil belajarpengantar pariwisata siswa digunakan korelasi product moment.

\section{HASIL PENELITIAN DAN PEMBAHASAN}

\section{Pengaruh Implementasi Model Pembelajaran Kooperatif Tipe Two Stay Two Stray dan Model Pembelajaran Konvensional Terhadap Kompetensi Pedagogik Guru}

Analisis deskriptif tentang kompetensi pedagogik dengan menggunakan model pembelajaran kooperatif tipe TSTS menunjukkan bahwa rata-rata skor kompetensi pedagogik dengan menggunakan model pembelajaran kooperatif tipe TSTS adalah 149,61 lebih besar dari rata-rata kompetensi pedagogik dengan menggunakan pembelajaran konvensional yaitu sebesar 135,39. Begitupula dengan rata-rata skor hasil belajar dengan menggunakan model pembelajaran kooperatif tipe TSTS yaitu sebesar 31,25 lebih besar dari rata-rata hasil belajar 
dengan menggunakan pembelajaran konvensional yaitu sebesar 25,61. Oleh karena itu dapat disimpulkan bahwa kompetensi pedagogik dengan menggunakan model pembelajaran kooperatif tipe TSTS lebih baik daripada kompetensi pedagogik dengan menggunakan pembelajaran konvensional dan hasil belajar dengan menggunakan model pembelajaran kooperatif tipe TSTS lebih baik daripada hasil belajar dengan menggunakan pembelajaran konvensional.

Hasil uji hipotesis pertama telah berhasil menolak hipotesis nol yang menyatakan bahwa tidak terdapat perbedaan hasil belajar ilmu gizi antara siswa yang menggikuti model pembelajaran kooperatif tipe Two Stay Two Straydengan siswa yang mengikuti model pembelajaran konvensionaldengan skor $F A_{\text {hitung }}=93,960$, dan $p<0,05$. Dari rata-rata skor hasil belajar dengan menggunakan model pembelajaran kooperatif tipe TSTS $=31,25$ dan rata-rata skor hasil belajar dengan menggunakan pembelajaran konvensional 25,61. Sehingga secara keseluruhan, hasil belajar dengan menggunakan model pembelajaran kooperatif tipe TSTS lebih tinggi daripada hasil belajar dengan menggunakan pembelajaran konvensional.Dari hasil uji hipotesis tersebut mengisyaratkan bahwa model pembelajaran kooperatif tipe TSTS lebih unggul dalam meningkatkan hasil belajar.

Hasil penelitian tersebut sejalan dengan penelitian yang dilakukan Sri Mahyuni (2013) yang berjudul "Pengaruh Penerapan Model Pembelajaran Kooperatif Tipe Two Stay Two Stray (TSTS)Terhadap Hasil Belajar Kimia Kelas XI IPA SMA Negeri 1 Selemadeg Ditinjau Dari Gaya Berpikir". Hasil penelitian menunjukkan bahwa, 1) terdapat perbedaan hasil belajar kimia: (a) antara siswa yang mengikuti model pembelajaran kooperatif tipe TSTS dengan siswa yang mengikuti model pembelajaran konvensional, memberikan dampak signifikan terhadap hasil belajar dengan harga Fhitung= 4,832 pada taraf signifikansi $5 \%$;(b) antara siswa yang memiliki gaya berpikir divergen dengan siswa yang memiliki gaya berpikir konvergen dengan Fhitung= 16,493 pada taraf signifikansi 5\%;(c) antara siswa yang mengikuti model pembelajaran TSTS dengan siswa yang mengikuti model pembelajaran konvensional bagi siswa yang memiliki gaya berpikir divergen dengan Fhitung=14,071, pada taraf signifikansi 5\%;(d) antara siswa yang memiliki gaya berpikir divergen dengan siswa yang memiliki gaya berpikir konvergen pada model pembelajaran TSTS dengan Fhitung= 19,217 pada taraf signifikansi 5\%;(2) Terdapat pengaruh interaksi antara model pembelajaran yang digunakan dengan gaya berpikir yang dimiliki siswa terhadap hasilbelajar kimia dengan Fhitung9,563 untuk taraf signifikansi 5\%;3) Tidak terdapat perbedaan hasil belajar kimia: (a) antara siswa yang mengikuti model pembelajaran TSTS dengan siswa yang mengikuti model pembelajaran konvensional bagi siswa yang memiliki gaya berpikir konvergen dengan Fhitung $=0,398$ untuk taraf signifikansi $5 \%$ sebesar 4,098 dan (b) antara siswa yang memiliki gaya berpikir divergen dengan siswa yang memiliki gaya berpikir konvergen pada model pembelajaran konvensional dengan Fhitung= 0,702 pada taraf signifikansi 5\% sebesar 4,098.Dengan demikian model pembelajaran kooperatif tipe TSTS dapat digunakan sebagai alternatif pembelajaran guna meningkatkan hasil belajar kimia.

Beberapa model yang dapat dilakukan di dalam menentukan keberhasilan hasil belajar siswa, salah satu diantaranya adalah model pembelajaran kooperatif tipe two stay two stray. Model pembelajaran kooperatif tipe two stay two stray adalah merupakan suatu model pembelajaran dimana siswa belajar memecahkan masalah bersama anggota kelompoknya, kemudian dua siswa dari kelompok tersebut bertukar informasi ke dua anggota kelompok lain yang tinggal. Dalam model pembelajaran kooperatif tipetwo stay two stray (dua tinggal dua tamu), siswa dituntut untuk memiliki tanggungjawab dan aktif dalam setiap kegiatan pembelajaran.

Model pembelajaran kooperatif tipe two stay two stray (TSTS) yaitu salah satu tipe pembelajaran kooperatif yang memberikan kesempatan kepada kelompok membagikan hasil dan informasi kepada kelompok lain. Pembelajaran two stay two stray memungkinkan siswa untuk saling berbagi informasi dengan kelompok-kelompok lain. Penggunaan model pembelajaran kooperatif tipe TSTS akan mengarahkan siswa untuk aktif, baik dalam 
berdiskusi, tanya jawab, mencari jawaban, menjelaskan dan juga menyimak materi yang dijelaskan oleh teman.Model pembelajaran two stay two stray ini memberi kesempatan kepada kelompok untuk mengembangkan hasil informasi dengan kelompok lainnya.

Berbeda dengan model pembelajaran konvensional, yang dimaksud dengan pembelajaran konvensional adalah pembelajaran yang biasa dilakukan guru dalam proses pembelajaran di kelas. Pada pembelajarankonvensional, proses belajar mengajar lebih sering diarahkan pada aliran informasiatau transferpengetahuan dari guru ke siswa. Konsep yang diterima hampir semua berasal dari apa kata guru. Guru menganggap belajar adalah sematamata mengumpulkan atau menghafalkan fakta-fakta yang tersaji dalam bentuk informasi atau materi pelajaran. Ciri pembelajarankonvensional adalah guru aktif tetapi siswa pasif,pembelajaran terpusat pada guru, tranfer pengetahuan yang dilakukan adalah dari guru kepada siswa.

Berdasarkan perbedaan antara model pembelajaran kooperatif tipe two stay two stray dengan model pembelajaran konvensional maka dapat diduga akan terjadi perbedaan hasil belajar antara siswa yang belajar mengunakan model pembelajaran kooperatif tipe two stay two stray dengan siswa yang belajar menggunakan model pembelajaran konvensional.

\section{Pengaruh Model Pembelajaran Kooperatif Tipe Two Stay Two Stray dengan Model Pembelajaran Konvensional setelah Kovariabel Kompetensi Pedagogik Dikendalikan}

Kedua,terdapat perbedaan hasil belajar ilmu gizi antara siswa yang mengikuti model pembelajaran kooperatif tipe Two Stay Two Stray dengan siswa yang mengikuti model pembelajaran konvensional setelah kovariabel kompetensi pedagogik gurudikendalikan. Hasil uji hipotesis kedua telah berhasil menolak hipotesis nol yang menyatakan tidak terdapat pengaruh yang signifikan antara model pembelajaran kooperatif tipe Two Stay Two Stray (TSTS) terhadap hasil belajar ilmu gizi siswa kelas Xjurusan Tata Bogadi SMK Negeri 2 Singaraja setelah kovariabel kompetensi pedagogik guru dikendalikan. Hal ini tampak dengan melihat harga $F_{\text {hitung }}$ sebesar 4,526 $>F_{\text {tabel }}=4,00$ nilai signifikansi lebih kecil daripada 0,05 yaitu sebesar 0,037 . Hal ini berarti hipotesis nol $\left(\mathrm{H}_{0}\right)$ di tolak dan hipotesis $1\left(\mathrm{H}_{1}\right)$ yang menyatakan bahwa "terdapat perbedaan hasil belajar ilmu gizi antara siswa yang mengikuti model pembelajaran kooperatif tipe Two Stay Two Stray dengan siswa yang mengikuti model pembelajaran konvensional setelah kovariabel kompetensi pedagogik guru dikendalikan", diterima.

Hasil ini sekaligus membuktikan bahwa hasil belajar siswa dengan menggunakan model pembelajaran kooperatif tipe TSTS memang lebih baik daripada hasil belajar siswa yang mengikuti pembelajaran konvensional sekalipun ditinjau dari kompetensi pedagogiknya.Temuan dalam penelitian ini juga sejalan dengan hasil penelitian yang dilakukan oleh Rosmawati pada tahun 2013 dengan judul PenggunaanModel Pembelajaran Kooperatif TwoStay Two Stray (TSTS) dalam Upaya Meningkatkan Hasil Belajar Siswa pada Mata PelajaranMatematika Sub Bab Menentukan Kelipatan danFaktor Bilangan(Penelitian Tindakan KelasPada Siswa Kelas IV MI Bangsal). Hasil penelitian pada penelitian ini menunjukkan setelah diterapkannyamodel pembelajaran kooperatif Teknik TSTS (Two Stay Two Stray) siswa lebih bersemangat dalam mengikuti proses pembelajaran matematika dan meningkatnya hasil belajar siswa pada mata pelajaran matematika. Sehingga penerapan model pembelajaran kooperatif Teknik TSTS (Two Stay Two Stray) berperan penting dalam upaya peningkatan hasil belajar siswa. Penggunaan model pembelajaran kooperatif two stay two stray (TSTS) di MI Bangsal, khususnya mata pelajaran Matematika pada tiap siklus secara garis besar mengalami peningkatan tiap siklusnya.Hal ini dapat dilihat dari semakin mantapnya pemahaman siswa terhadap materi yang disampaikan guru (ketuntasan belajar meningkat dari siklusl, II, dan II) yaitu masing-masing73,07\%, 84,61\%, dan 96,15\%. Perkembangan hasil belajar siswa di MI Bangsal setelah dilakukan proses pembelajaran pada seluruh siklus dengan menggunakan model pembelajaran kooperatiftwo stay two stray (TSTS) mengalami peningkatan, proses 
pembelajaran lebih menarik bagi siswa sehingga siswa lebih antusias dalam proses pembelajaran.

Peran guru sebagai tenaga pengajar di sekolah menempati posisi paling strategis dan sentral dalam kehidupan pengelolaan pembelajaran.Hal ini mengandung pengertian bahwa keberhasilan atau kegagalan sekolah mencapai tujuan, salah satunya ditentukan oleh guru, baik secara pribadi maupun secara kelompok.Kualitas pengelolaan pembelajaran tidak bisa dilepaskan dari kompetensi pedagogik guru.Profesionalisme menjadi tuntutan dari setiap pekerjaan. Apalagi profesi guru yang sehari-hari menangani benda hidup yang berupa anakanak atau siswa dengan berbagai karakteristik yang masing-masing tidak sama. Pekerjaan sebagai guru menjadi lebih berat tatkala menyangkut peningkatan kemampuan anak didiknya, sedangkan kemampuan dirinya mengalami stagnasi.Guru yang profesional adalah mereka yang memiliki kemampuan profesional dengan berbagai kapasitasnya sebagai pendidik.

Model pembelajaran kooperatif tipe two stay two stray adalah model pembelajaran kooperatif dengan teknik setiap kelompok membagikan hasil atau informasi kepada kelompok lain. Langkah-langkah pembelajaran kooperatif tipe two stay two stray adalah siswa berkelompok kemudian setiap kelompok diberi permasalahan yang harus mereka diskusikan jawabannya. Setelah diskusi dalam kelompok, dua dari anggota kelompok bertamu ke kelompok lain untuk mendapatkan informasi. Dua anggota dari kelompok tetap tinggal untuk membagikan informasi kepada tamu yang datang.Setelah semua informasi didapatkan, mereka kembali ke kelompok masing-masing untuk berdiskusi mengenai informasi yang diperoleh.

Pada model pembelajaran konvensional, proses belajar mengajar lebih sering diarahkan pada aliran informasi atau transfer pengetahuan dari guru ke siswa. Konsep yang diterima hampir semua berasal dari apa kata guru. Guru menganggap belajar adalah semata-mata mengumpulkan atau menghafalkan fakta-fakta yang tersaji dalam bentuk informasi atau materi pelajaran.

Berdasarkan pemaparan di atas dapat diketahui terdapat perbedaan pengaruh model pembelajaran kooperatif tipe two stay two stray dengan model pembelajaran konvensional setelah kovariabel kompetensi pedagogik dikendalikan.

\section{Kontribusi Kovariabel Kompetensi Pedagogik Guru Terhadap Hasil Belajar Ilmu Gizi Siswa}

Ketiga, terdapat kontribusi kompetensi pedagogik terhadap hasil belajar.Kompetensi pedagogik dalam penelitian ini memberikan kontribusi positif terhadap hasil belajar, walaupun tetap dipengaruhi oleh faktor-faktor yang lainnya.Kontribusi kovaribel kompetensi pedagogik terhadap hasil belajar, ditunjukan dengan melihat harga $r_{\text {hitung }}$ sebesar 0,845 yang lebih besar dari pada $r$ tabel $(0,215)$. Keselarasan $r^{2}$ sebesar 0,714 yang berarti $71,4 \%$ perubahan pada hasil belajar dapat diterangkan oleh kompetensi pedagogik. Dengan demikian, kompetensi pedagogik memang berkontribusi positif terhadap hasil belajar.

Berkaitan dengan kegiatan Penilaian Kinerja Guru terdapat 7 (tujuh) aspek yang berkenaan penguasaan kompetensi pedagogik. Berikut ini disajikan ketujuh aspek kompetensi pedagogik beserta indikatornya: 1) Menguasai karakteristik peserta didik. Guru mampu mencatat dan menggunakan informasi tentang karakteristik peserta didik untuk membantu proses pembelajaran. 2) Menguasasi teori belajar dan prinsip-prinsip pembelajaran yang mendidik. Guru mampu menetapkan berbagai pendekatan, strategi, metode, dan teknik pembelajaran yang mendidik secara kreatif sesuai dengan standar kompetensi guru. 3) Pengembangan kurikulum. Guru mampu menyusun silabus sesuai dengantujuan terpenting kurikulum dan menggunakan RPP sesuai dengan tujuan dan lingkungan pembelajaran. 4) Kegiatan pembelajaran yang mendidik. Guru mampu menyusun dan melaksanakan rancangan pembelajaran yang mendidik secara lengkap. Guru mampu melaksanakan kegiatan pembelajaran yang sesuai dengan kebutuhan peserta didik. Guru mampu menyusun dan menggunakan berbagai materi pembelajaran dan sumber belajar sesuai dengan karakteristik peserta didik. 5) Pengembangan potensi peserta didik. Guru mampu menganalisis potensi 
pembelajaran setiap peserta didik dan mengidentifikasi pengembangan potensi peserta didik melalui program pembelajaran yang mendukung siswa mengaktualisasikan potensi akademik, kepribadian, dan kreativitasnya sampai ada bukti jelas bahwa peserta didik mengaktualisasikan potensi mereka. 6) Komunikasi dengan peserta didik. Guru mampu berkomunikasi secara efektif,empatik dan santun dengan peserta didik dan bersikap antusias dan positif. 7) Penilaian dan Evaluasi. Guru mampu menyelenggarakan penilaian proses danhasil belajar secara berkesinambungan. Guru melakukan evaluasi atas efektivitas proses dan hasil belajar dan menggunakan informasi hasil penilaian dan evaluasi untuk merancang program remedial dan pengayaan.

Berdasarkan aspek-aspek yang terdapat pada kompetensi pedagogik guru, maka dapat dikatakan terdapat kontribusi kovariabel kompetensi pedagogik guru terhadap hasil belajar ilmu gizi siswa.

\section{PENUTUP} berikut.

Berdasarkan hasil pengujian hipotesis dan pembahasan, dapat ditarik simpulan sebagai

Pertama, terdapat pengaruh yang signifikan model pembelajaran kooperatif Two Stay Two Stray terhadap hasil belajar ilmu gizi siswa kelas $X$ Jurusan Tata Boga di SMKN 2 Singaraja. Hasil belajar siswa dengan menggunakan model pembelajaran kooperatif tipe TSTS lebih tinggi dari pada hasil belajar menggunakan pembelajaran konvensional. Kualifikasi hasil belajar dengan menggunakan model pembelajaran kooperatif tipe TSTS berada pada katagori sangat tinggi, dan hasil belajar dengan menggunakan pembelajaran konvensional berada pada katagori tinggi.

Kedua, terdapat pengaruh yang signifikan model pembelajaran kooperatif Two Stay Two Stray terhadap hasil belajar ilmu gizi siswa kelas X Jurusan Tata Boga di SMKN 2 Singaraja setelah kovariabel kompetensi pedagogik guru dikendalikan..

Ketiga, terdapat kontribusi yang signifikan kovariabel kompetensi pedagogik guru terhadap hasil belajar ilmu gizi siswa.Berdasarkan temuan-temuan di atas dapat disimpulkan bahwa model pembelajaran kooperatif tipe TSTS berpengaruh terhadap hasil belajar baik sebelum maupun setelah kovariabel kompetensi pedagogik dikendalikan.

Saran yang dapat diajukan pada penelitian ini adalah sebagai berikut.

Kepada guru diharapkan agar menerapkan model pembelajaran kooperatif tipe Two Stay Two Stray dalam proses pembelajaran, karena sudah terbukti dapat meningkatkan hasil belajar siswa.

Melihat keterbatasan waktu dan pokok bahasan yang digunakan dalam penelitian ini, maka disarankan penelitian lain agar melaksanakan penelitian sejenis dengan pemilihan variabel yang berbeda dan waktu yang lebih lama untuk mendapatkan gambaran yang lebih meyakinkan mengenai pengaruh model pembelajaran kooperatif tipe TSTS terhadap hasil belajar ditinjau dari kompetensi pedagogik guru. Dalam penelitian ini variabelnya juga dapat dikembangkan sehingga nantinya dapat memperoleh hasil yang lebih baik.

\section{DAFTAR RUJUKAN}

Agung, Anak Agung Gede. 2014. Metodologi Penelitian Pendidikan. Malang: Aditya Media Publishing.

Agung, Anak Agung Gede. 2016. Statistika Dasar untuk Pendidikan.Yogyakarta; Depublish.

Arikunto, S. 2005. Manajemen penelitian. Jakarta: Rineka Cipta.

Arikunto, S. 2006. Prosedur Penelitian Suatu Pendekatan Praktik. Jakarta: Rineka Cipta. 
Lie, Anita. 2010. Cooperative Learning Mempraktikkan Cooperative Learning di Ruang-Ruang Kelas. Jakarta: Grasindo.

Lindgren, H.C.1967. Educational Psychology in The Calssroom. New York: Wiley and Sons.

Rosmawati, Iros. 2013.Penggunaan Model Pembelajaran Kooperatif Two Stay Two Stray (TSTS) dalam Upaya Meningkatkan Hasil Belajar Siswa pada Mata Pelajaran Matematika Sub Bab Menentukan Kelipatan dan Faktor Bilangan (Penelitian Tindakan Kelas Pada Siswa Kelas IV MI Bangsal). E-journal.Program Peningkatan Kualifikasi S-1 Bagi Guru Mi dan Pai Melalui Dual Mode System (DMS) LPTK lainsyekh Nurjati Cirebon.

Rusyana, Yus. 2006. Peranan Tradisi Lisan dalam Ketahanan Budaya. Jakarta: Direktorat.

Sri Mahyuni, Ni Wayan. 2013. Pengaruh Penerapan Model Pembelajaran Kooperatif Tipe Two Stay Two Stray (TSTS) Terhadap Hasil Belajar Kimia Kelas XI IPA SMA Negeri 1 Selemadeg Ditinjau Dari Gaya Berpikir. e-journal UniversitasPendidikan Ganesha. Program Studi Administrasi Pendidikan. Volume 5 Tahun 2013.

Sugiyono. 2008. Metode Penelitian Kunatitatif Kualitatif dan R\&D. Bandung: Alfabeta.

Sukmadinata, Nana Syaodih. 2009. Metode Penelitian Pendidikan. Bandung: Rosdakarya.

Suprijono, Agus. 2009. Cooperative Learning Teori \& Aplikasi Paikem. Yogyakarta: Pustaka Pelajar. 